\title{
Fundamentals of Biometry
}

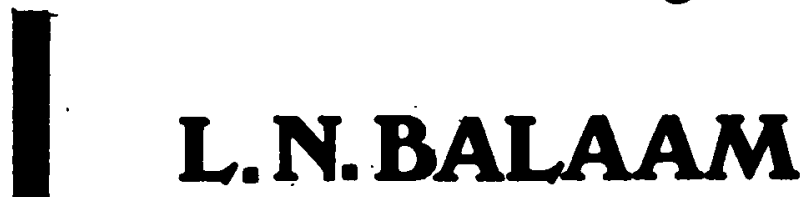

Director of Biometric Services, University of Sydney

A fundamental course in biometry, an essential part of the training of all biological scientists, cannot be presented without the necessary mathematical tools. In the unhurried development of this work these are introduced gradually within the text, the only prerequisite being some arithmetic and simple algebra. With this grounding the research worker will have the confidence and skill to make a proper use of biometrical methods.

£4.90; paperback $£ 2.95$

\section{George Allen \& Unwin}


Allen, E. J. The effect of row width on the yield of three potato varieties. (With 1 text-figure)

PAQUAY, R., DE BAERE, R. and LOUSSE, A. Influences of diet and body condition on the nitrogen utilization in the cow. (With 1 text-figure) . . . . . . . . . .

Onwueme, I. C. and LAude, H. M. Heat-induced growth retardation and attempts at its prevention in barley and wheat coleoptiles . $. \quad . \quad . \quad . \quad . \quad . \quad . \quad$.

Borhami, B. E. A. and El-ShazLy, K. A relationship between thyroid activity, acetate infusion and food intake in rams. (With 1 text-figure) . . . . . . . . . .

Widdowson, F. V., Penny, A. and Flint, R. C. Results from an experiment comparing aqueous ammonia with 'Nitro-Chalk' for grazed grass. (With 2 text-figures) . . .

Widdowson, F. V., Penny, A. and Flint, R. C. Results from barley experiments comparing aqueous ammonia and aqueous urea with ammonium nitrate, and also liquid with granular NPK fertilizers .

Davis, R. H., HASSAN, O. E. M. and SyKes, A. H. The adaptation of energy utilization in the laying hen to warm and cool ambient temperatures. 


\section{THE JOURNAL OF AGRICULTURAL SCIENCE}

\section{CONTENTS}

\section{Vol. 79 Part 2 October 1972}

WALKER, D. M. Calcium and phosphorus retention by the milk-fed lamb, with estimates of the

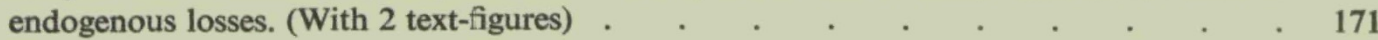

MAHADIK, S. R. Effects of nitrogen and its carriers with different topping heights on growth, yield and quality of tobacco. (With 2 text-figures) . . . . . . . . . .

ToDD, J. R. Copper, molybdenum and sulphur contents of oats and barley in relation to chronic copper poisoning in housed sheep. (With 5 text-figures) . . . . . . . . . 191

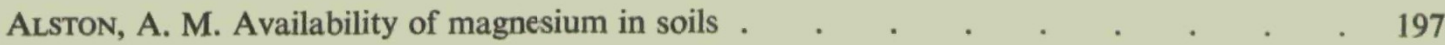

CharLes, A. H. Ryegrass populations from intensively managed leys. III. Reaction to management, nitrogen application and Poa trivialis L. in field trials

Bolton, J. Changes in magnesium and calcium in soils of the Broadbalk wheat experiment at Rothamsted from 1865 to 1966 . (With 4 text-figures)

BUNTING, E. S. Ripening in maize: interrelationships between time, water content and weight of dry material in ripening grain of a flint $\times$ dent hybrid (Inra 200). (With 4 text-figures)

BUNTING, E. S. Ripening of grain maize in England: varietal differences in ripening patterns. (With 7 text-figures).

Wright, A. J. A theoretical appraisal of the relative merits of $50 \%$ hybrid and synthetic varieties of grasses

Brockington, N. R. A mathematical model of pasture contamination by grazing cattle and the effects on herbage intake. (With 1 text-figure) .

LEAKEY, C. L. A. The effect of plant population and fertility level on yield and its components in two determinate cultivars of Phaseolus vulgaris (L.) Savi

DÝRMUNDSSON, Ó. R. and LEES, J. L. Effect of rams on the onset of breeding activity in Clun Forest ewe lambs. (With 1 text-figure)

JoHns, G. G. The accuracy of a range of capacitance probe methods for estimating pasture yields. (With 2 text-figures)

GRAY, D. Spacing and harvest date experiments with Maris Peer potatoes. (With 6 text-figures)

REID, D. The effects of the long-term application of a wide range of nitrogen rates on the yields from perennial ryegrass swards with and without white clover. (With 7 text-figures)

Peart, J. N., Edwards, R. A. and Donaldson, Elizabeth. The yield and composition of the milk of Finnish Landrace $\times$ Blackface ewes. (With 5 text-figures)

Continued on the inside back cover

(C) Cambridge University Press, 1972

SUBSCRIPTIONS. Two volumes of three parts are published annually. The subscription price is $£ 9.00$ net (U.S.A. $\$ 28.50$ ) per volume (post free); single parts are available at $£ 4.00$ net (U.S.A. $\$ 12.00$ ) plus postage. Orders or enquiries may be sent to any bookseller or subscription agent, or to Cambridge University Press, P.O. Box 92, London NW1 2DB. (U.S.A. and Canada, Cambridge University Press, American Branch, 32 East 57th Street, New York, N.Y.10022, U.S.A.) 